\title{
Customer Perception of Service Quality, Price Fairness and Brand-image of Telecommunication Service Providers in Ghana and Its Impact on Customer Satisfaction and Loyalty
}

\author{
Emmanuel Sampson Ansah \\ Department of Economics and Management, Zhejiang Normal University, No. 688 Yinbing Avenue, \\ Jinhua, Zhejiang, China
}

\begin{abstract}
The rapid development and aggressive competition in the marketing segment in the telecommunication network industry coupled with increasing emergence of new service providers in Ghana has called for strategies aiming at enhancing and optimizing the customer loyalty of existing customer as well attracting newly potential customers. It is against this background that Customer loyalty has taken the center stage in the telecommunication network marketing. Motivated by this, the paper examined the extent to which customer perceptions on service quality, service price fairness and brand image of the telecommunication service providers in Ghana influence customer loyalty. A total sample of two hundred and fifteen (215) customers of the telecommunication service providers in three regions in Ghana were randomly selected for the study. The structural equation modeling with the Smart PLS-SEM computer software version 3.0 was used to analysis the data collected. The results revealed that, there is a positive significant impact of customer perceptions on service quality, service price fairness, and brand image customer loyalty. There is also a positive significant impact of customer perceptions on service quality, service price fairness, and brand image on customer satisfaction. The mediation mechanism analysis also confirmed that customer satisfaction served as a partial mediation between customer perceptions on service quality, service price fairness, and brand image and customer loyalty. The study recommends that, Telecommunication network providers in Ghana place particular emphasis on improving their network, pricing, branding, coverage, connection, voice call, and overall network quality to improve customer satisfaction and loyalty .
\end{abstract}

Keywords: Telecommunication Network Providers, Ghana, Customer Loyalty, Customer perception

DOI: $10.7176 / \mathrm{JMCR} / 75-02$

Publication date: January $31^{\text {st }} 2021$

\section{Introduction}

Telecommunication was sseen as and has been the fast-growing industries prior to the last decades. The evolution of telecommunication sectors has affected growth at all levels, from individual, firms, to organizations at the regional, national level, to global level. In the last two decades, the Governments of Ghana have restructured the telecommunication sector with the sole aim of elevating competition and improving reliability and affordability of service to the public (NCA, 2004), resulting in quick development and aggressiveness in the competitive market. This has prompted the telecommunications sector to produce an array of products, services and advertising messages targeted at maintaining the existed customers base as well serving as an attractive mechanism to newly and potential customers (NCA, 2004).

Some telecommunication operators who have launched their own switching benefits to entice consumers of their competitors, have certainly made some of the telecommunication operators perceive there is the threat of losing some of their consumers or customers to persuasive offers from other operators. Due to this, the sole aim of enhancing corporate image is to ensure corporate success as a priority undertaken by telecommunication operators (Nguyen \& Leblanc, 2001; Zeithaml, Berry, \& Parasuraman, 1996). The main strategy in service that have strongly stand firm is the quality of service and its management. Per Berry et al., (1988), Sservice quality is seen as a big distinguishing feature which serves as a tool that combat a vibrant competitive organization and as such all serious businesses, firms or organizations seems to acquired that.

The perception customers get about service quality is based on the extensiveness of agreements deduced between their expectations and experiences. It is only when customers are easily convinced thats where the customer feels satisfied. Offering and practicing strong service quality in the organization is one of the greatest mechanism that promote the organization's success and makes it very unique in the competitive market (Parasuraman et al., 1991). It is therefore important to ensure and practice service quality (Parasuramam, 1995), by exceeding the expectations of customers (Berry \& Parasuramam 1991; Klose, Wren 1988), rather than just a mere satisfaction of the needs and wants of a customer (Brown et al., 1992; Timmers \& Wiele, 1990).

Generally, there has been some concerns about the quality of service been provided by the various players in the Ghana telecommunication and its development causing subscribers been unsatisfied. As aforementioned, poor service quality is championing the dissatisfaction and which has seen as national concerns reported by the National Communications Authority (NCA) (BIZ Community.com, October 19, 2007). Since the past decade, the industry 
has witnessed a tremendous increase in subscriber growth rate for all the mobile telecommunication operators (ITU, 2008).

Though there has still been an increasing rate of subscribers have in telecommunication services of Ghana, it does not proof the total satisfaction level of customers per the service quality rendered by telecommunication service providers in Ghana. The subscribers in the telecommunication services are repeatedly criticizing the telecommunication service providers due to the low and flaws in their quality of service rendered to the users. This has caused customers to hold two or three sim-cards of the telecommunication service providers in Ghana due to dissatisfaction on the part of the customers.

Looking into the above problem, it has call for much debate among social psychologists, marketing administrators, entrepreneurs and researchers.

The main of objective of the research is to examine customer perception that leads to the customer satisfaction and their loyalty among the telecommunication service providers;

i. To examine the relationships between customers' perceptions on brand image, service quality and service price fairness towards the telecommunication service providers in Ghana and customer satisfaction.

ii. To investigate how customer perceptions on service quality, brand image and service price fairness affects customer loyalty of telecommunication service provider in Ghana.

iii. To examine the mediation effect of customer satisfaction on the impact of customer perceptions towards service quality, brand image, and service price fairness on customer's loyalty of the telecommunication service provider in Ghana.

The rest of the paper is structure into brief literature, methodology, results, discussions, conclusions and recommendations.

\section{Brief Literature and hypotheses development}

The Governments of Ghana with many efforts have restructured the telecommunication sector with the sole aim of elevating competition and improving reliability and affordability of service to the public, resulting in quick development and competitive aggressiveness in the market. Due to those efforts on the part of the government, it has prompted the telecommunications sector to produce an array of products, services and advertising messages targeted at maintaining the existed customer base as well as creating attractiveness for the newly potential customers. The mobile telecommunication industry has become intensely challenging and tough to an arena to operate in (Kim and Yoon, 2004; Seo, Rangathan, and Babad, 2008). The industry has become forthright competitive and growing at a gargantuan rate during the last several years. The notable growth in the mobile telephone technology market can be a predicate to overwhelming technical adduces including the increased number of telecommunication operators, following in a savage competition (Gerpott, Rams, and Schinler, 2001). Therefore telecommunication is seen as one of the prime support service system essential for rapid growth and also keeping the business world in its pace of abreast of economy (V. Nigam, T. Thakur, V.K. Sethi, R.P. Singh, 2012). Some telecommunication operators who have launched and develop their own tactics like switching benefits to entice customers of their competitors, and have certainly made some of the telecommunication operators perceive there is the threat of losing some of their customers in a persuasive way.

Customer loyalty, is a deep held commitment shown in re-buying a preferable product or service offered consistently or repeatedly in the future, irrespective of circumstances that may control and other strategic marketing activities targeting the potential customer to switch (Oliver, 1997). Customer Perception refers to way sensory information is organized, interpreted, and consciously experienced about the services obtained. As these concepts are interrelated with customer Satisfaction, the later is generally presented as an emotional state resulting from the positive or negative disconfirmation of the initial expectations during an ownership or a consumption experience (Oliver, 1980). Nevertheless, recent research has shown that this transactional and cognitive conception, referring to a single standard comparison (initial expectations) is far from sufficient to identify the formation process of satisfaction. Satisfaction amounts to comparing expected and perceived quality (Sireix and Dubois, 1999). However, many marketing researchers have challenged this proposition by presenting satisfaction as a direct result of perception (Anderson and Alii, 1994; Carman, 1990; Parasuraman and Alii 1994). In this regard, Cronin and Taylor (1992) assume that offer and service perception is a better way to determine overall satisfaction than comparing expected quality and perceived quality.

However, many marketing researchers have challenged this view by presenting satisfaction as directly resulting from perceived quality (Anderson and Alii, 1994; Carman, 1990; Parasuraman and Alii, 1994). In this context, Cronin and Taylor (1992) believe that perceived quality is a better determinant of overall satisfaction than comparing expected and perceived quality. It is the fact that perception of the investors is the good predictor of the customer satisfaction. Sectors of telecommunications are from the perception customers may hold about a highly powerful and reliable quality of network coverage and this is one of the most core service drivers among the players of telecommunications service (Lai et al., 2009), willingness and available team support for customers (Aydin and Özer, 2005), provision of informative support websites availability (Thaichon et al., 2012) and an 
esteemed security and privacy level that is trusted by customers (Roca et al., 2009). The activeness, capabilities, and quality of network signals on the online services sector is strictly base on the quality level of the said network (Wang et al., 2004), numerous available errors, the speed in downloading and uploading (Vlachos and Vrechopoulos, 2008). Customers may see low quality of service when they realize failure in the connections of internet usage. All these may affect the satisfaction level when customers realize low quality of service failure in connectivity of network and it automatically does not lead to loyalty.

Studies has also depicted that, the positive responds of perception of brand image and price fairness influence customer's level of satisfaction which in a way demonstrate the good performance of that particular organization. In fact, the level of customer perception been high in terms of service quality, brand image and service price fairness portrays high level of the customer satisfaction (Ganesh et al., 2000; Caruana, 2002). Ganesh et al. (2000) reports shows that if an organization's service performed is outstandingly greater than expected results for the customer, it shows a great satisfaction level which triggers a greater patronage by customer which may increase the market share of the organization. Based on this, the study hypothesizes that,

Hypothesis 1: There is a positive significant relationship between customer perception on service quality and customer satisfaction

Hypothesis 2: There is a positive significant association between customer perception on service price fairness and customer satisfaction.

Hypothesis 3: There is a positive significant relationship between customer perception on brand image and customer satisfaction

3.8.2 Relation between customer perception on service quality, service price fairness, and brand image and customer loyalty

Perceived service quality refers to the degree of discrepancy between customer's normative expectations for the service and their perception of service's performance (Parasuraman, A., Zeithaml V. A., and Berry L. L., 1988). According to Fornell (1992), high service quality, brand image and price fairness lead to high level of customer retention which can constitute for profitability. It has been found that perceived service quality, price and reputation are positively related to repurchase intention, recommendation, and resistance to attractive and better alternatives (Bloomer, J., Ruyter, K. and Wetzels, M., 1998; Jones, M. A., Beatty, S. E., and Mothersbaugh, D. V., 2002). Amin et al. (2012) found perceived service quality, service price fairness, brand image, trust and switching cost are positively related to customer loyalty towards telecommunication service provider. Hence it is hypothesized that,

Hypothesis 4: There is a positive significant relationship between service quality and customer loyalty Hypothesis 5: There is a positive relationship between service price fairness and customer loyalty Hypothesis 6: There is a positive relationship between brand image and customer loyalty

\subsubsection{Mediation Role of customer satisfaction in the relationship between customer perception and customer} loyalty

There is a belief that satisfied a customer is likely to do future purchase and maintain loyal to the telecommunication service provider. This forms the basis of market concept. Incurrent bends, the service quality from the telecommunication service provider is essential for the development and building of customer loyalty in the light of competition. Coyne (1986), propose two thresholds link between customer satisfaction and customer loyalty. When satisfaction is at highest point loyalty increases whiles loyalty decreases when there is low satisfaction (Oliva, Oliver \& MacMillan, 1992)

According to Rust and Zahorik (1993) there is a direct effect of customer satisfaction on loyalty. Auh and Johnson (2005) asserted that there are strong relationships between satisfaction and loyalty. Likewise, Bodet (2008) also prove the relationship between customer satisfaction and customer loyalty. There is positively correlation between satisfaction and loyalty (Shankar, Smith and Rangaswamy, 2003). Vesel and Zabkar (2009) also prove that customer satisfaction is one of the determinants of customer loyalty. Therefore this study hypothesizes that, Hypothesis 7: There is a positive significant relationship between customer satisfaction and customer loyalty Hypothesis 8: Customer satisfaction significantly mediates relationship between service quality and customer loyalty.

Hypothesis 9: Customer satisfaction significantly mediates relationship between service price fairness and customer loyalty.

Hypothesis 10: Customer satisfaction significantly mediates relationship between brand image and customer loyalty.

\section{Methodology}

The study was conducted in Ghana where 215 customers of six key telecommunication network providers in three regions were randomly selected for the study. These respondents comprised inhabitants of Kumasi, Accra and Takoradi cities in Ghana who are subscribers and customers of the Telecommunication network service providers namely Vodafone, MTN, Tigo, Aitel, Expreeso, and Glo. The structure questionnaires were used as the main 
instruments for the study. The questionnaires were designed based on Likert Scale (ranging from 1-stringly Disagree to 5-strongly agree). The study utilized the partial least squares Structural Equation Modeling (PLS-SEM) to investigate the various pathways and mechanisms through which Customer satisfaction dimensions (service quality, service price fairness and brand image) influence customer loyalty. The use of structural equation modeling, the Smart PLS has been proven to be effective software for such analysis involving latent variables and mediation effect (Hair, Ringle \&Sarstedt, 2013). According to (Hair et al., 2013) the PLS technique has high accuracy, ability and produces a better results than other methods which usually use covariance approach. In this study, both structural model and measurement model were estimated to ensure validity of outcome and accuracy of results. Both direct and indirect pathways of the structural relationships were estimated using the bootstrapping approach.

\section{Results and Discussion}

Table 1: Descriptive statistics of Construct Items

\begin{tabular}{|c|c|c|c|}
\hline $\begin{array}{l}\text { Observed Indicator Items Latent variable construct } \\
\text { items }\end{array}$ & $\begin{array}{l}\text { Latent Variables } \\
\text { Construct indicators }\end{array}$ & Mean & $\begin{array}{l}\text { Standard } \\
\text { Deviation }\end{array}$ \\
\hline $\begin{array}{l}\text { 1. All employees perform activities in a caring } \\
\text { manner in terms of having personal interaction }\end{array}$ & SQ1 $\leftarrow$ Service Quality & 4.09 & 1.08 \\
\hline $\begin{array}{l}\text { 2. The service provider offers fast and convincing } \\
\text { customer service and support }\end{array}$ & SQ2 $\leftarrow$ Service Quality & 4.04 & 1.11 \\
\hline $\begin{array}{l}\text { 3. I think service providers have good customer care } \\
\text { and provide good quality service subscribers to do } \\
\text { their job well }\end{array}$ & SQ3 $\leftarrow$ Service Quality & 4.16 & 1.11 \\
\hline $\begin{array}{l}\text { 4. I think the service providers and their employees } \\
\text { are trustworthy }\end{array}$ & BIM1 $\leftarrow$ Brand Image & 4.22 & .97 \\
\hline $\begin{array}{l}\text { 5. My service provider takes social responsibility } \\
\text { seriously }\end{array}$ & BIM2 $\leftarrow$ Brand Image & 3.73 & 1.50 \\
\hline 6. My service provider has a reputation for quality & BIM3 $\leftarrow$ Brand Image & 3.83 & 1.40 \\
\hline $\begin{array}{l}\text { 7. My service provider has a positive image in the } \\
\text { minds of consumers as they provide affordable } \\
\text { calls and internet plans to us. }\end{array}$ & $\begin{array}{l}\text { PF1 } \leftarrow \text { Service } \quad \text { Price } \\
\text { Fairness }\end{array}$ & 3.74 & 1.43 \\
\hline 8. Myserviceprovideroffers goodvalue formoney. & $\begin{array}{l}\text { PF2 } \leftarrow \text { service Price } \\
\text { Fairness }\end{array}$ & 3.07 & 1.50 \\
\hline $\begin{array}{l}\text { 9. My serviceprovider offers overall better pricing plan } \\
\text { compared to its competitors }\end{array}$ & $\begin{array}{l}\text { PF3 } \leftarrow \text { service Price } \\
\text { Fairness }\end{array}$ & 3.80 & 1.38 \\
\hline 10. Overall quality of Internet services. & $\begin{array}{l}\text { CSA } \leftarrow \text { Customer } \\
\text { Satisfaction }\end{array}$ & 3.09 & 1.45 \\
\hline 11. Ease of network connection & $\begin{array}{l}\text { CSA2 } \leftarrow \text { Customer } \\
\text { Satisfaction }\end{array}$ & 3.72 & 1.45 \\
\hline 12. Coverage of the network. & $\begin{array}{l}\text { CSA3 } \leftarrow \text { Customer } \\
\text { Satisfaction }\end{array}$ & 3.78 & 1.45 \\
\hline 13. Call Voice quality of calls. & $\begin{array}{l}\text { CSA4 } \leftarrow \text { Customer } \\
\text { Satisfaction }\end{array}$ & 3.18 & 1.63 \\
\hline $\begin{array}{l}\text { 14. Switch to another service provider will bring great } \\
\text { lose to me economically }\end{array}$ & $\begin{array}{l}\text { CL1 } \leftarrow \text { Customer } \\
\text { Loyalty }\end{array}$ & 3.40 & 1.43 \\
\hline $\begin{array}{l}\text { 15. Changing my service provider will not bring any } \\
\text { difference in my life. }\end{array}$ & $\begin{array}{l}\text { CL2 } \leftarrow \text { Customer } \\
\text { Loyalty }\end{array}$ & 3.14 & 1.29 \\
\hline $\begin{array}{l}\text { 16. I don't have for the energy required in switching to } \\
\text { another service provider }\end{array}$ & $\begin{array}{l}\text { CL3 } \leftarrow \text { Customer } \\
\text { Loyalty }\end{array}$ & 3.52 & 1.32 \\
\hline $\begin{array}{l}\text { 17. It is inconvenient for me to switch to the other } \\
\text { service provider }\end{array}$ & $\begin{array}{l}\text { CL4 } \leftarrow \text { Customer } \\
\text { Loyalty }\end{array}$ & 3.44 & 1.44 \\
\hline $\begin{array}{l}\text { 18. The cost, time and energy for changing my current } \\
\text { service provider will be high for me. }\end{array}$ & $\begin{array}{l}\text { CL5 } \leftarrow \text { Customer } \\
\text { Loyalty }\end{array}$ & 3.55 & 1.45 \\
\hline
\end{tabular}

The study examined five main latent variables namely (customer's perception on Service quality, customers' perception on Service price fairness, and customers' perception on Brand image, customers' satisfaction and customers' loyalty) with respect to the kind of services by the telecommunication service providers in Ghana. The study utilized questionnaire item constructs designed with Likert scale type ranging from (1-strongly Disagree to 5 -strongly agree)

Results from the Table 1 above, customers' perception on Service quality has construct items with means 
ranging from 4.04-4.16 implying that the respondents on the average agreed to the instrument items, customers' perception on Service price fairness (Mean = 3.07-3.8) which also implies agreement of the respondents on the items while the average responses of respondents on the Brand Image constructs ranged from 3.73-4.22 also within the agreement range. The low standard deviations shows that, there were not wide variations in their responses. Again, from the Table 1, the measurement construct items for the Customer Satisfaction latent variables has the man values ( 3.09-3.78) while customer loyalty had mean values (3.14 -3.55) with minimum standard Deviations. The factor loadings, reliability and validity of these item constructs were tested using the Smart PLS and the results presented (see Table 2 and 3 below)

\section{Measurement Model}

The measures model examines how the observed construct items are fitted, reliable and valid to proceed for the analysis of the structural model. The reliability and fitness of the model are tested in the smart PLS-SEM using the Factor Loading as confirmatory test, composite Reliability (CR), Discriminant validity, Average variance extracted (AVE), Cronbach's Alpha, and R-squared as indicated in Table 8, 9 and 10 below. These measurement were computed to check if the factors and indicators were significantly effective in measuring the latent variable as well as the explanatory power of the model. According to Hyduk and Littvay, 2012) if the AVE and CR have loading less than 0.5 and 0.7 correspondingly, it implies a weak convergence validity and are not desired to be maintained for the analysis. Results from Table 3 shows that, the CR for all the indicators are above 0.7 which implies that, the requirements are met. Similarly, the AVE for all the indicators are also above 0.5 which shows that, the items indicators are well loaded

Table 2: Factor Loadings of Measurement Constructs

\begin{tabular}{|c|c|c|c|c|}
\hline Latent variable constructs & $\begin{array}{l}\text { Factor } \\
\text { loadings }\end{array}$ & $\begin{array}{l}\text { Standard } \\
\text { (STDEV) }\end{array}$ & $\begin{array}{l}\text { Tr Statistics } \\
(\mid \text { O/STDEV } \mid)\end{array}$ & $\begin{array}{l}\mathbf{P} \\
\text { Values }\end{array}$ \\
\hline BIM1 $\leftarrow$ Brand Image & 0.896 & 0.017 & 52.838 & 0.000 \\
\hline 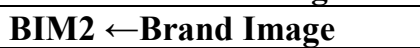 & 0.910 & 0.011 & 79.581 & 0.000 \\
\hline BIM3 Ł- Brand Image & 0.793 & 0.030 & 26.539 & 0.000 \\
\hline CL1 $\leftarrow$ Customer Loyalty & 0.836 & 0.026 & 32.731 & 0.000 \\
\hline CL2 $\leftarrow$ Customer Loyalty & 0.677 & 0.042 & 16.063 & 0.000 \\
\hline CL3 $\leftarrow$ Customer Loyalty & 0.900 & 0.011 & 82.399 & 0.000 \\
\hline CL4 $\leftarrow$ Customer Loyalty & 0.675 & 0.037 & 18.353 & 0.000 \\
\hline CL5 Ł- Customer Loyalty & 0.811 & 0.029 & 28.016 & 0.000 \\
\hline $\begin{array}{ll}\text { CSA } & \leftarrow \text { Customer } \\
\text { Satisfaction } & \end{array}$ & 0.879 & 0.016 & 56.191 & 0.000 \\
\hline $\begin{array}{l}\text { CSA2 } \leftarrow \quad \text { Customer } \\
\text { Satisfaction }\end{array}$ & 0.868 & 0.015 & 58.349 & 0.000 \\
\hline $\begin{array}{l}\text { CSA3 } \leftarrow \quad \text { Customer } \\
\text { Satisfaction }\end{array}$ & 0.757 & 0.026 & 28.698 & 0.000 \\
\hline $\begin{array}{l}\text { CSA4 } \leftarrow \text { Customer } \\
\text { Satisfaction }\end{array}$ & 0.736 & 0.031 & 23.696 & 0.000 \\
\hline PF1 $\leftarrow$ Price Fairness & 0.660 & 0.048 & 13.640 & 0.000 \\
\hline PF2 $\leftarrow$ Price Fairness & 0.760 & 0.039 & 19.524 & 0.000 \\
\hline PF3 ᄂPrice Fairness & 0.820 & 0.025 & 32.667 & 0.000 \\
\hline SQ1 $\leftarrow$ Service Quality & 0.802 & 0.043 & 18.577 & 0.000 \\
\hline SQ2 $\leftarrow$ Service Quality & 0.823 & 0.040 & 20.429 & 0.000 \\
\hline SQ3 $\leftarrow$ Service Quality & 0.879 & 0.027 & 32.985 & 0.000 \\
\hline
\end{tabular}

The results from Table 2 reveal that, all the factor loadings obtained from PLS Bootstrapping presented are above 0.5 which indicates that, the construct items were well loaded and satisfied to be used for the analysis. The p-values indicate that, the measurements were statistically significant at $1 \%$ level.

\section{Reliability and explanatory power of the construct and estimated models}

Reliability and validity test was conducted for the constituent elements for the independent and dependent variables. The items predicted consistency within the measurement for Cronbach's alpha, which showed good internal reliability for all the items (Bagozzi, 1993 \& Hair et al, 2010).

The results from Table 3 shows the latent variables measured from the observed construct items are more reliable and consistent to measure the model and to estimate the structural relationships. The results show that, all the latent variable is reliable as the necessary benchmark values to satisfy to be reliable were met. The Cronbach's Alpha values $(\alpha)$ are all above 7.0 while CR and AVE and Rho_A are also above 0.5 which means the model is more reliable. 
More import, the R-squared was used to measure the explanatory power of the structural equation model and the extent to which the model explains the variation in the dependent variable (Customer satisfaction and customer loyalty). The results show that R-squared of 0.409 implies that, the model explain almost $41 \%$ of the changes in the dependent variable customer loyalty while the model also explains the changes in the customer satisfaction as a dependent variable and a mediator by almost $40 \%$.

Table 3: Construct reliability and R-squared

\begin{tabular}{|l|l|l|l|l|l|}
\hline Latent variables & $\begin{array}{l}\text { Cronbach's } \\
\text { Alpha }\end{array}$ & rho_A & $\begin{array}{l}\text { Composite } \\
\text { Reliability }\end{array}$ & $\begin{array}{l}\text { Average Variance Extracted } \\
\text { (AVE) }\end{array}$ & $\begin{array}{l}\text { R- } \\
\text { square } \\
\text { d }\end{array}$ \\
\hline Brand Image & 0.834 & 0.836 & 0.901 & 0.754 & - \\
\hline Customer Loyalty & 0.840 & 0.848 & 0.888 & 0.616 & $0.409-$ \\
\hline $\begin{array}{l}\text { Customer } \\
\text { Satisfaction }\end{array}$ & 0.826 & 0.832 & 0.885 & 0.660 & 0.399 \\
\hline Price Fairness & 0.709 & 0.612 & 0.793 & 0.562 & - \\
\hline Service Quality & 0.813 & 0.978 & 0.874 & 0.698 & - \\
\hline
\end{tabular}

The model is well fitted and demonstrate efficient estimations. The discriminant validity of the measurement variable are also demonstrated below

Table 4: Discriminant Validity (Fornell-Larcker Criterion)

\begin{tabular}{|l|l|l|l|l|l|}
\hline Latent variables & $\begin{array}{l}\text { Brand } \\
\text { Image }\end{array}$ & $\begin{array}{l}\text { Customer } \\
\text { Loyalty }\end{array}$ & $\begin{array}{l}\text { Customer } \\
\text { Satisfaction }\end{array}$ & $\begin{array}{l}\text { Price } \\
\text { Fairness }\end{array}$ & $\begin{array}{l}\text { Service } \\
\text { Quality }\end{array}$ \\
\hline Brand Image & 0.868 & & & & \\
\hline Customer Loyalty & 0.513 & 0.785 & & & \\
\hline $\begin{array}{l}\text { Customer } \\
\text { Satisfaction }\end{array}$ & 0.529 & 0.490 & 0.812 & & \\
\hline Price Fairness & 0.524 & 0.560 & 0.530 & 0.750 & \\
\hline Service Quality & 0.300 & 0.322 & 0.376 & 0.307 & 0.835 \\
\hline
\end{tabular}

The results from the Table 4 presents the Discriminant Validity of the measurement latent variables using Fornell-Larcker Criterion. The diagonals of the major leading values exceed their minor lower values which satisfy the Fornell-Larcker Criterion hence well fitted for the analysis of the model. The structure of the measurement model is indicated in figure 1 .

The figure presents the factor ladings, coefficients of the direct effects, the R-squared values and the structural relationships as explained in the previous sections. The structural model confirms how reliable the latent variable constructs were measured and how suitable to be used to analyses the structural equation relationships and impacts. The model has three independent variables representing the three dimensions of customer perceptions, one mediator, and one dependent variable.

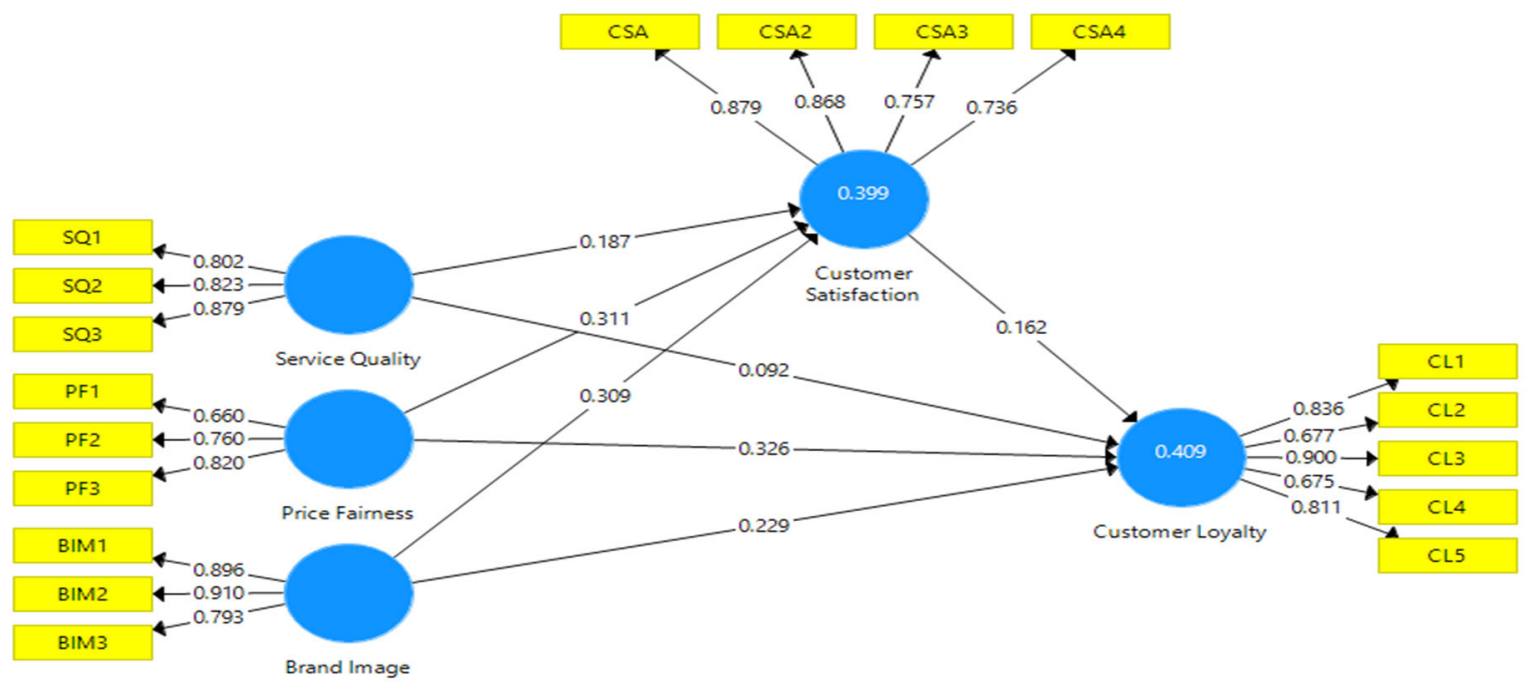

Figure 1: Measurement model with Factor loading of indicator items 


\section{Results from Structural Model}

The results from the structural model presents the coefficient estimates of direct and indirect effect of customer perceptions dimensions on customer royalty of telecommunication service providers in Ghana. The Table 5 below shows the total direct effects and the pathway coefficients of the independents latent variables on the dependent variable while the direction of the arrow shows the pathway of effect as shown below.

Table 5: Direct path Effect coefficients

\begin{tabular}{|l|l|l|l|l|}
\hline Structural relationships & $\begin{array}{l}\text { Coefficien } \\
\mathbf{t} \\
(\boldsymbol{\beta})\end{array}$ & Standard Deviation & T Statistics & P Values \\
\hline Brand Image $\rightarrow$ Customer Loyalty & 0.279 & 0.058 & 4.813 & $\mathbf{0 . 0 0 0}$ \\
\hline Brand Image $\rightarrow$ Customer Satisfaction & 0.309 & 0.063 & 4.948 & $\mathbf{0 . 0 0 0}$ \\
\hline Customer Satisfaction $\rightarrow$ Customer Loyalty & 0.162 & 0.069 & 2.338 & $\mathbf{0 . 0 2 0}$ \\
\hline Price Fairness $\rightarrow$ Customer Loyalty & 0.377 & 0.059 & 6.396 & $\mathbf{0 . 0 0 0}$ \\
\hline Price Fairness $\rightarrow$ Customer Satisfaction & 0.311 & 0.065 & 4.812 & $\mathbf{0 . 0 0 0}$ \\
\hline Service Quality $\rightarrow$ Customer Loyalty & 0.122 & 0.044 & 2.811 & $\mathbf{0 . 0 0 5}$ \\
\hline Service Quality $\rightarrow$ Customer Satisfaction & 0.187 & 0.048 & 3.912 & $\mathbf{0 . 0 0 0}$ \\
\hline
\end{tabular}

The results from Table 5 show that, customer perception dimensions such as Brand Image $(\beta=0.279, \mathrm{P}<0.01)$, Service price fairness $((\beta=0.377, \mathrm{P}<0.01)$, and service quality $(\beta=0.122, \mathrm{P}<0.01)$ have statistically significant and positive direct impact on customer loyalty. These imply that, as service quality, Brand image and service price fairness increase from the perspectives of the customers, the customer loyalty also increase significantly.

Findings from the Table 5 also show that, customer perception dimensions such as Brand Image $(\beta=0.309$, $\mathrm{P}<0.01)$, Service price fairness $((\beta=0.311, \mathrm{P}<0.01)$, and service quality $(\beta=0.187, \mathrm{P}<0.01)$ have statistically significant and positive direct impact on Customer satisfaction. This means that, as the dimensions of customer perception on the services provided by the telecommunication networks increase, their satisfactions also increase positively.

Table 5 also shows that, customer satisfaction $(\beta=0.162, \mathrm{P}<0.05)$, has a positive and statistically significant direct impact on customer loyalty at $5 \%$ level. The results mean that, as customer satisfaction increase, their loyalty also increase in the same directions. The table 6 below also present the mediation effect of customer satisfaction in the impact of customer perception dimensions on customer loyalty.

\section{Mediation Aanalysis}

The table 6 below used mediating mechanism to test the relationship between customer perception dimensions and customer loyalty with customer satisfaction serving as a mediator. Biased-corrected bootstrapped method from Smart PLS-SEM with 95\% confidence interval (CI) was used to examine the relationships indirect effects. Results from the study are presented in the Table 6 below

Table 6: Mediation Effect of customer satisfaction (specific indirect effects)

\begin{tabular}{|l|l|l|l|l|}
\hline Structural relationships & $\begin{array}{l}\text { Coefficie } \\
\mathbf{n t} \\
(\boldsymbol{\beta})\end{array}$ & $\begin{array}{l}\text { Standard } \\
\text { Deviation }\end{array}$ & $\begin{array}{l}\text { T } \\
\text { Statistics }\end{array}$ & $\begin{array}{l}\text { P } \\
\text { Values }\end{array}$ \\
\hline $\begin{array}{l}\text { Brand Image } \rightarrow \text { Customer Satisfaction } \rightarrow \text { Customer } \\
\text { Loyalty }\end{array}$ & 0.050 & 0.022 & 2.266 & 0.024 \\
\hline $\begin{array}{l}\text { Price Fairness } \rightarrow \text { Customer Satisfaction } \rightarrow \text { Customer } \\
\text { Loyalty }\end{array}$ & 0.050 & 0.027 & 1.872 & 0.062 \\
\hline $\begin{array}{l}\text { Service Quality } \rightarrow \text { Customer Satisfaction } \rightarrow \\
\text { Customer Loyalty }\end{array}$ & 0.030 & 0.016 & 1.897 & 0.058 \\
\hline
\end{tabular}

satisfaction. The results show that, as Brand Image $(\beta=0.050, P<0.05)$, Service price fairness $((\beta=0.050$, $\mathrm{P}<0.1)$, and service quality $(\beta=0.030, \mathrm{P}<0.1)$ have statistically significant and positive indirect impact on customer loyalty at $5 \%, 10 \%$ and $10 \%$ levels through the mediating variable Customer satisfaction. The results show that, customer satisfaction serves as a Partial mediation between consumer perception dimensions and customer loyalty. Without the mediation effect, the customer perception dimensions have a greater impact than passing though customer satisfactions.

The figure 2 below shows the structural model estimated in the study show the weight and the significant $t$ values obtained through Bootstrapping with Smart PLS-SEM

This model of bootstrap weighted path diagram confirms the significant level of the structural relationships and impact of the independent variables on the depend variables.

The study examines the mechanism through which customer perceptions on service quality, service price fairness 
and brand image indirectly influence customer loyalty through a mediation variable Customer

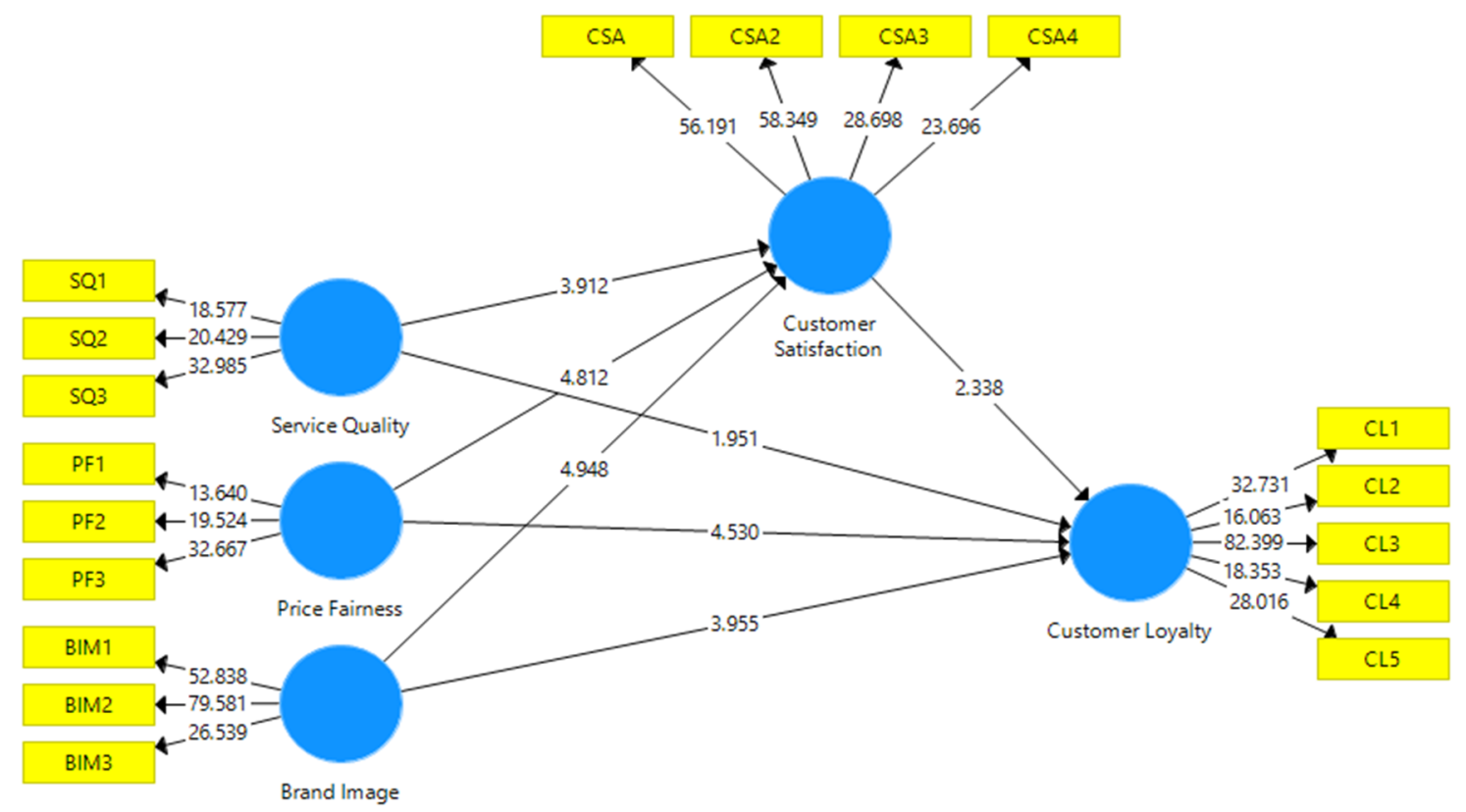

Figure 2: Structural model of bootstrap weighted path diagram

Testing of hypothesis

Table 7: Testing of hypothesis of structural Relationships of the Direct Relationships

\begin{tabular}{|l|l|l|l|l|}
\hline $\begin{array}{l}\text { Testing of hypotheses of the } \\
\text { Structural relationships }\end{array}$ & $\begin{array}{l}\text { Coefficient } \\
(\beta)\end{array}$ & $\begin{array}{l}\text { Standard } \\
\text { Deviation }\end{array}$ & P Values & $\begin{array}{l}\text { Hypothesis supported or } \\
\text { not supported }\end{array}$ \\
\hline $\begin{array}{l}\text { H1:Service Quality } \rightarrow \text { Customer } \\
\text { Satisfaction }\end{array}$ & 0.187 & 0.048 & 0.000 & Hypothesis supported \\
\hline $\begin{array}{l}\text { H2: Price Fairness } \rightarrow \text { Customer } \\
\text { Satisfaction }\end{array}$ & 0.311 & 0.065 & 0.000 & Hypothesis supported \\
\hline $\begin{array}{l}\text { H3: Brand Image } \rightarrow \text { Customer } \\
\text { Satisfaction }\end{array}$ & 0.309 & 0.063 & 0.000 & Hypothesis supported \\
\hline $\begin{array}{l}\text { H4:Service Quality } \rightarrow \text { Customer } \\
\text { Loyalty }\end{array}$ & 0.122 & 0.044 & 0.005 & Hypothesis supported \\
\hline $\begin{array}{l}\text { H5: Price Fairness } \rightarrow \text { Customer } \\
\text { Loyalty }\end{array}$ & 0.377 & 0.059 & 0.000 & Hypothesis supported \\
\hline $\begin{array}{l}\text { H6:Brand Image } \rightarrow \text { Customer } \\
\text { Loyalty }\end{array}$ & 0.279 & 0.058 & 0.000 & Hypothesis supported \\
\hline $\begin{array}{l}\text { H7: Customer Satisfaction } \rightarrow \\
\text { Customer Loyalty }\end{array}$ & 0.162 & 0.069 & 0.020 & Hypothesis supported \\
\hline $\begin{array}{l}\text { H8: Service Quality } \rightarrow \text { Customer } \\
\text { Satisfaction Customer Loyalty }\end{array}$ & 0.030 & 0.016 & 0.058 & Hypothesis supported \\
\hline $\begin{array}{l}\text { H9: Price Fairness } \rightarrow \text { Customer } \\
\text { Satisfaction } \rightarrow \text { Customer Loyalty }\end{array}$ & 0.050 & 0.027 & 0.062 & Hypothesis supported \\
\hline $\begin{array}{l}\text { H10:Brand Image } \rightarrow \text { Customer } \\
\text { Satisfaction } \rightarrow \text { Customer Loyalty }\end{array}$ & 0.050 & 0.022 & 0.024 & Hypothesis supported \\
\hline
\end{tabular}

Results from Table 7 test the various hypotheses (H1-H10) underlying the study. From hypothesis 1,2 and 3 , the results support that, customer perceptions on service quality, service price fairness individually have positive and significant impact on customer satisfaction towards the telecommunication service providers in Ghana. This implies that, increasing the positive perception of the Telecommunication network subscribers on their service quality, service price, and brand image increase the customers' satisfaction in subscribing to these telecommunication networks providers. Again, results from the hypothesis testing show a strong agreement with previous studies who also found that, the level of customer perception been high in terms of service quality, brand image and service price fairness portray high level of the customer satisfaction (Ganesh et al., 2000; Caruana, 2002). Similarly, from hypotheses 4, 5, and 6, the results confirm and support the assertion that, customer perceptions on service quality, service price fairness individually have positive and significant impact on customer loyalty towards the telecommunication service providers in Ghana. As the customers develop a strong positive 
perception towards service quality, price fairness and brand image of these telecommunication service providers, their loyalty defined as repeated usage of a product or service also increases.

Hypothesis 7 posit that, customer satisfaction has a significant positive relationship with customer loyal and this is confirmed and supported from the results. Practically, as customers developed high satisfaction towards particular service, they tend to use that service repeatedly thereby increasing their loyalty towards that service. The positive significant relationship between customers' perception on service quality, service price fairness, brand image and customer loyalty emerged from the hypothesis test strongly confirms findings from previous scholars such as (Bloomer, J., Ruyter, K. and Wetzels, M., 1998; Jones, M. A., Beatty, S. E., and Mothersbaugh, D. V., 2002; Amin et al. 2012).

From the mediation analysis as indicated in Hypothesis 8,9 and 10, customer satisfaction partially mediates the relationship between

Service quality and customer loyalty, service price fairness and customer loyalty, and Brand Image, and customer loyalty. The results support that, customer satisfaction serves as a partial mediation between Customer perception dimensions and customer loyalty. Findings from the study are in line with previous studies such as Shankar, Smith and Rangaswamy, (2003), Vesel and Zabkar (2009) Johnson (2005) who also found and proves that customer satisfaction is one of the determinants of customer loyalty. This implies that, is telecommunication service providers particularly in Ghana are able to increase the satisfaction of their customers, it would drive their feelings and emotions to retained retain patronage of their network services provided hence becoming loyal to the service providers.

From the model, it was shown that perception predicted satisfaction, the hypothesis was supported. This showed that when customer tends to perceived positive on a product, it increases their satisfaction towards the product that is being satisfy with the service provided by Telecommunication service provider.

\section{Conclusions and Recommendations}

This study findings show that customers' satisfaction can help explain why customers' perceptions are not the same across customers'. Customers' loyalty is influenced by customers' satisfaction which cause customers' perception. Although the study results do not differ significantly from the previous results, our population-based sample had more power in explaining the relationships. This study shows that organizations should also be aware that individuals perceive satisfaction in different ways. It is important that these individual differences are acknowledged as important markers of individual well-being, and that Telecommunication companies should try to alleviate the concerns regarding dissatisfactions raised by customers.

As the current Telecommunication service providers have fewer tangible resources to offer customers, satisfaction factors such as quality services become ever more important.

\section{References}

1. Jones, M. A., Beatty, S. E., and Mothersbaugh, D. V. (2002). Switching Barriers and Repurchase Intention in Services. Journal of Retailing, 76 (2), 259-274.

2. Ganesh, J., Arnold, M. J., and Reynolds, K. E. (2000). Understanding the Customer Base of Service Providers: An Examination of The Differences Between Switchers and Stayers. Journal of Marketing. 64, 65-87.

3. Hayduk, L. A., \& Littvay, L. (2012). Should researchers use single indicators, best indicators, or multiple indicators in structural equation models? BMC medical research methodology, 12(1), 159.

4. Hair, J. F., Ringle, C. M., \& Sarstedt, M. (2013). Partial least squares structural equation modeling: Rigorous applications, better results and higher acceptance. Long range planning, 46(1-2), 1-12.

5. Vlachos, A., Vrechopoulos, P., (2008). Determinants of behavioral intentions in the mobile internet services market. J. Serv. Mark. 22 (4), 280-291.

6. Thaichon, P., Lobo, A., Mitsis, A., (2012). Investigating the antecedents to loyalty of Internet service providers in Thailand: Developing a conceptual model. Paper presented at the Australian and New Zealand Marketing Academy Conference, Adelaide, Australia.

7. Roca, J., García, J., Vega, J., 2009. The importance of perceived trust, security and privacy in online trading systems. Inf. Manag. Comput. Secur. 17 (2), 96-113.

8. Lai, F., Griffin, M., Babin, B., (2009). How quality, value, image, and satisfaction create loyalty at a Chinese telecom. J. Bus. Res. 62, 980-986.

9. Aydin, S., \& Ozer, G. (2005). The analysis of antecedents of customer loyalty in the Turkish mobile telecommunication market, European Journal of Marketing, 39(7), 910-925.

10. Gerpott, T.J., Rams, W., \& Schindler, A. (2001). Customer retention, loyalty, and satisfaction in the German mobile cellular telecommunication market.

11. Kim, H.S. \& Yoon, C.H. (2004). Determinants of subscriber churn and customer loyalty in the Korean Mobile telephony market. Telecommunication Policy, 28, 751-765.

12. Seo, D., Ranganathan, C., and Babad, Y. (2008). Two-level model of customer retention in the US mobile 
telecommunications service market. Telecommunication Policy, 32, 751-765.

13. V. Nigam, T. Thakur, V.K. Sethi, R.P. Singh, (2012) Benchmarking of Indian mobile telecommunication operators using DEA with sensitivity analysis, Benchmark.: Int. J. 19 (2012) 219-238.

14. National Communications Authority Newsletter (2004). Volume 4, number 13.

15. Nguyen, N. and Leblanc, G. (2001). Corporate image and Corporate Reputation in consumers' Retention Decisions in Services. Journal of Retailing and Consumer Services No. 8, 227-36. 